\title{
Transgenic Expression of Embryonic MAP2 in Adult Mouse Brain: Implications for Neuronal Polarization
}

\author{
Kathryn M. Marsden, Thierry Doll, Jacqueline Ferralli, Florence Botteri, and Andrew Matus \\ Friedrich Miescher Institute, Basel, 4002 Switzerland
}

The major neuronal microtubule-associated protein MAP2 is selectively localized in dendrites, where its expression is under strong developmental regulation. To learn more about its potential effects on neuronal morphogenesis and its sorting within the neuronal cytoplasm, we have raised transgenic mice that express high levels of the embryonic form, MAP2c, in the adult brain. One transgenic line expressed higher levels of MAP2C than endogenous adult MAP2. This had no detectable effect on either the arrangement or morphology of neurons, suggesting that although MAP2c is necessary for neuronal morphogenesis it is not involved in its regulation. Like endogenous adult MAP2, transgenic MAP2c was present in dendrites but not axons, indicating that the signal responsible for its cytoplasmic sorting is contained within the $1.5 \mathrm{~kb}$ of its coding sequence. In situ hybridization with specific probes showed that transgenic
MAP2c mRNA was limited to cell bodies. Thus, the dendritic localization of MAP2c protein cannot be the result of previous transport of its mRNA but must depend on a signal associated with the protein itself. Furthermore, because the amino acid sequence of MAP2c is present in all forms of MAP2, this signal is also contained within adult high- $M_{r}$ MAP2 protein. This raises the possibility that, rather than the conventional scheme of mRNA sorting preceding protein localization, the transport of adult MAP2 mRNA into dendrites could depend on it being part of a translation complex in which the targeting signal is on the nascent protein.

Key words: neuronal differentiation; dendrites; cytoskeleton; polarization; transgenic; microtubules; morphogenesis; development; brain; nervous system; mouse
The polarized form of neurons depends on the targeting of appropriate structural molecules into either axons or dendrites (Craig and Banker, 1994). Among these the neuronal microtubule-associated protcin MAP2 provides a striking cxample, being present in dendrites but not axons (Matus et al., 1981; Bernhardt and Matus, 1984; Caceres et al., 1984; De Camilli et al., 1984; Matus et al., 1986). Because MAP2 has a profound influence on the organization of cellular microtubules (Lewis et al., 1989; Weisshaar et al., 1992) and their ability to support process outgrowth (Chen et al., 1992; Edson et al., 1993), this dendritic localization has correspondingly important implications for neuronal morphogenesis. The molecular mechanism responsible for sorting MAP2 within the neuronal cytoplasm is unknown. However, in situ hybridization studies have shown that MAP2 mRNA is also present in dendrites (Garner et al., 1988; Tucker et al., 1989; Bruckenstein et al., 1990; Kleiman et al., 1990) so that its localization there could depend in principle on previous targeting of the mRNA, from which the protein is then synthesized locally. The existence of mRNA-based sorting in a variety of systems, including Drosophila embryos (Berleth et al., 1988), Xenopus oocytes (Melton, 1987; Yisraeli and Melton, 1988), and $\beta$-actin in myocytes and fibroblasts (Sundell and Singer, 1990; Hill and Gunning, 1993), provides precedents for such a mechanism.

In addition to the adult high- $M_{\mathrm{r}}$ forms, MAP2a and MAP2b,

Received Aug. 7, 1995; revised Feb. 26, 1996; accepted Feb. 28, 1996.

K.M. was supported by a fellowship from the Wellcome Trust. We thank Dr. Nevis Fregien for supplying the chicken $\beta$-actin promoter, Drs. M. Goedert and S. Halpain for providing rabbit antibodies against tau and MAP2, respectively, Dr. Herman van der Putten for assistance with transgenic mouse techniques, and Dr. Grayson Richards for assistance with the in situ hybridization technique.

Correspondence should be addressed to Dr. Kathryn Marsden, Friedrich Miescher Institute, P.0. Box 2543, 4002 Basel, Switzerland.

Copyright (C) 1996 Society for Neuroscience $0270-6474 / 96 / 163265-09 \$ 05.00 / 0$
MAP2 also occurs as a smaller embryonic form, MAP2c, which is normally expressed only during development (Riederer and Matus, 1985; Garner and Matus, 1988). Immunohistochemical studies have shown that in most areas of the developing brain all forms of MAP2, including MAP2c, appear to be limited to dendrites (Greenough et al., 1978; Bernhardt and Matus, 1984; Burgoyne and Cumming, 1984). However, unlike the high- $M_{\mathrm{r}}$ forms, which are always dendritic, MAP2c occurs in the axons of developing motor neurons (Tucker et al., 1988; Albala et al., 1995) and retinal ganglion cells (Tucker and Matus, 1988). In two previous transfection studies, MAP2c was also found to enter axons. Meichsner et al. (1993) found that epitope-tagged MAP2c entered all processes of hippocampal neurons transfected in culture, and Kanai and Hirokawa (1995) reported similar findings for cultured motor neurons. To investigate the underlying sorting mechanism further, we have now raised transgenic mice that express epitope-labeled MAP2c in the adult brain. These animals allow the cytoplasmic distribution of MAP2c to be studied in both brain sections and primary cell cultures. The results show that, like the larger adult MAP2, MAP2c protein is restricted to dendrites in adult neurons. However, unlike the adult forms, the MAP2c mRNA does not enter dendrites but remains in cell bodies. These observations suggest the existence of a proteinbased mechanism capable of sorting MAP2 protein isoforms and their respective mRNAs within the neuronal cytoplasm.

In addition to targeting, we raised these MAP2c-transgenic mice to determine the consequences of prolonging the expression of this embryonic cytoskeletal protein beyond the time when it normally disappears from developing neurons. Rather, to our surprise, the expression of MAP2c in the adult brain at levels greater than endogenous adult MAP2 had no detectable effect on neuronal morphology. 
A

Lane 1, Control nontransgenic mouse; lane 2, a nontransgenic littermate to transgenic mice; lanes 3, 4, two independent transgenic mouse lines. Positions are indicated for endogenous adult high $M_{\mathrm{r}}$ MAP2 $(2 b)$, embryonic MAP2 $(2 c)$, and tubulin $(T)$.

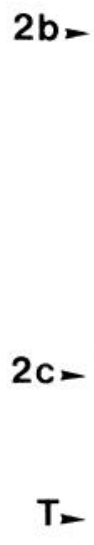

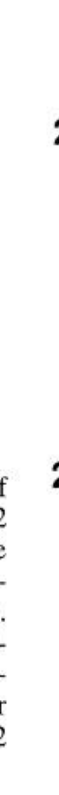

\section{MATERIALS AND METHODS}

Vector construction and raising of transgenic animals. cDNA encoding rat MAP2c (Doll et al., 1990), together with 33 bp encoding an N-terminal epitope tag from human c-myc (Munro and Pelham, 1987; Burgin et al., 1994), was subcloned into vector $\beta$ act-16, which contains chicken $\beta$-actin promoter sequences (Fregien and Davidson, 1986; Meichsner et al., 1993). A fragment containing promoter, coding, and required $3^{\prime}$ untranslated vector sequence was excised from the vector by digestion with restriction enzymes and purified by agarose gel electrophoresis before microinjection into oocytes as described previously (Botteri et al., 1987). Founder animals and progeny carrying the transgene were identified by Southern blot analysis of genomic DNA from tail clippings. Microtubules were isolated from brain homogenates by taxol precipitation (Vallee, 1982), and transgenic and endogenous forms of MAP2 were identified by Western blot analysis as described previously (Towbin et al., 1979).

Immunohistochemistry. Mice were deeply anesthetized with a mixture of $80 \mathrm{mg}$ of ketamine (Ketasol, Grueub) and $24 \mathrm{mg}$ of xylazin (Rompun, Bayer) per $\mathrm{kg}$ of body weight and fixed by transcardiac perfusion with $4 \%$ paraformaldehyde in $100 \mathrm{~mm}$ phosphate buffer, $\mathrm{pH}$ 7.4. After dissection, brains were immersed overnight in the same fixative and $40 \mu \mathrm{m}$ sections were cut on a Vibratome (Oxford Instruments). Immunoperoxidase staining was performed as described previously (Bernhardt and Matus, 1984).

\section{Cell culture and transfection.}

Hippocampal neuronal cell cultures from both transgenic and wild type mice were established at embryonic day 16 (E16) and grown over a glial feeder layer (Goslin and Banker, 1991). Transfection with $\beta$ act- 16 containing the coding sequences of either myc-MAP2c or bacterial chloramphenicol acetyl transferase (CAT) (Meichsner et al., 1993) was performed at the time of plating of the cells using a modified liposome-mediated (DOTAP; Boehringer Mannheim, Indianapolis, IN) procedure (Kaech et al., in press). Briefly, cells from E16 hippocampus were trypsinized, resuspended in HBSS at $4 \times 10^{6} \mathrm{cells} / \mathrm{ml}$, and treated with DOTAP $(20 \mu \mathrm{l} / \mathrm{ml})$. After $15 \mathrm{~min}$ at $37^{\circ} \mathrm{C}$, they were resuspended with the appropriate DNA at the required concentration (0.5-2.0 $\mu \mathrm{g} / \mathrm{ml}$ ) and incubated in suspension for another $40 \mathrm{~min}$ before plating for $6 \mathrm{hr}$ at $37^{\circ} \mathrm{C}$. Coverslips with the transfected cells were then inverted over a glial feeder layer as described previously (Goslin and Banker, 1991) and maintained for up to $15 \mathrm{~d}$ before fixation and staining. In each experiment, cells were fixed at three or more time points, on days $6,9,11$, or 15 after transfection, and assessed by immunostaining. Cells were fixed for $10 \mathrm{~min}$ with $1 \%$

\section{B}

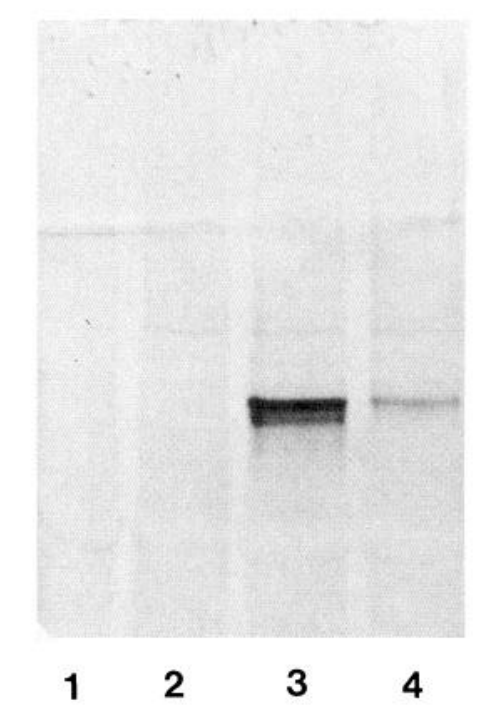

1

2

3

4
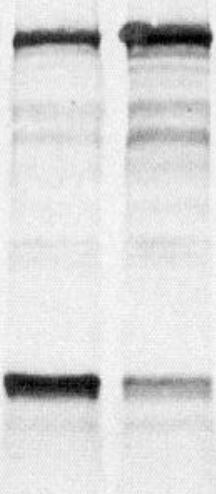

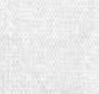

1

glutaraldehyde in PHEM buffer (60 mm PIPES, 25 mM HEPES, $10 \mathrm{~mm}$ EGTA, and $2 \mathrm{~mm} \mathrm{MgCl}_{2}$ ), $\mathrm{pH} 6.9$, and immunofluorescence double labeling was performed as described previously (Matus et al., 1986).

In situ hybridization. Fresh brain tissue was rapidly frozen in isopentane cooled in dry ice, sectioned at $12 \mu \mathrm{m}$ on a cryostat, and mounted on SuperFrost/Plus slides (Menzel-Glaser). Sections were fixed for $40 \mathrm{~min}$ at room temperature with $4 \%$ formaldehyde

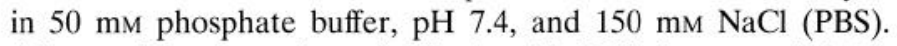
After washing three times for 5 min with PBS, they were hybridized overnight at $43^{\circ} \mathrm{C}$ with antisense oligonucleotides that had been end-labeled with $\left[{ }^{35} \mathrm{~S}\right] \mathrm{dATP}$ for $5 \mathrm{~min}$ at $37^{\circ} \mathrm{C}$ using the terminal transferase procedure. The sections were washed as follows: twice with $1 \times$ SSC plus $10 \mathrm{~mm}$ dithiothreitol (DTT) at $55^{\circ} \mathrm{C}$, twice with $0.5 \times \mathrm{SSC}$ plus $10 \mathrm{~mm}$ DTT at $55^{\circ} \mathrm{C}$ and, finally, once at room temperature with $0.5 \times \mathrm{SSC}$ plus $10 \mathrm{~mm}$ DTT. After being dipped in distilled water, they were dehydrated in a graded series of alcohols, air-dried, and exposed to $\beta$-max film (Amersham, Arlington Heights, IL) for 6 weeks. The antisense oligodeoxynucleotides used were: high- $M_{\mathrm{r}}$ MAP2, TACTGCCTCTGGCTCAGATGTAACTTTTCCCAAGGT; $\alpha$-tubulin, TGCTTGCCAGCTCCTGTCTCACTGAAGAAG; and MAP2c junction, ACCACTTGTTGCTTCTTCCAGTGCAGCTGT.

\section{RESULTS}

To distinguish transgenic MAP2c from endogenous adult MAP2, the transgene construct used in this study was tagged with a 10 -amino-acid epitope from the human c-myc gene. From 5 founder mice $(\mathrm{F} 0)$ containing transgene DNA inserted into the genome, two stable lines were established (Fig. 1 $A, B$ ), one of which expresses transgenic myc-MAP2c at levels higher than endogenous adult high- $M_{\mathrm{r}}$ MAP2 (Fig. $1 A$, lane 3 ). Western blot analysis of various tissues including skeletal muscle, heart, kidney, liver, lung, and testes failed to detect myc-MAP2c expression anywhere other than brain (data not shown). This presumably reflects the selective activity of the chick $\beta$-actin promoter sequence used to express the protein. Neuron-specific expression from $\beta$-actin promoters has also been reported in previous transfection studies of hippocampal cell cultures (Meichsner et al., 1993) and motor neurons (Kanai and Hirokawa, 1995). 


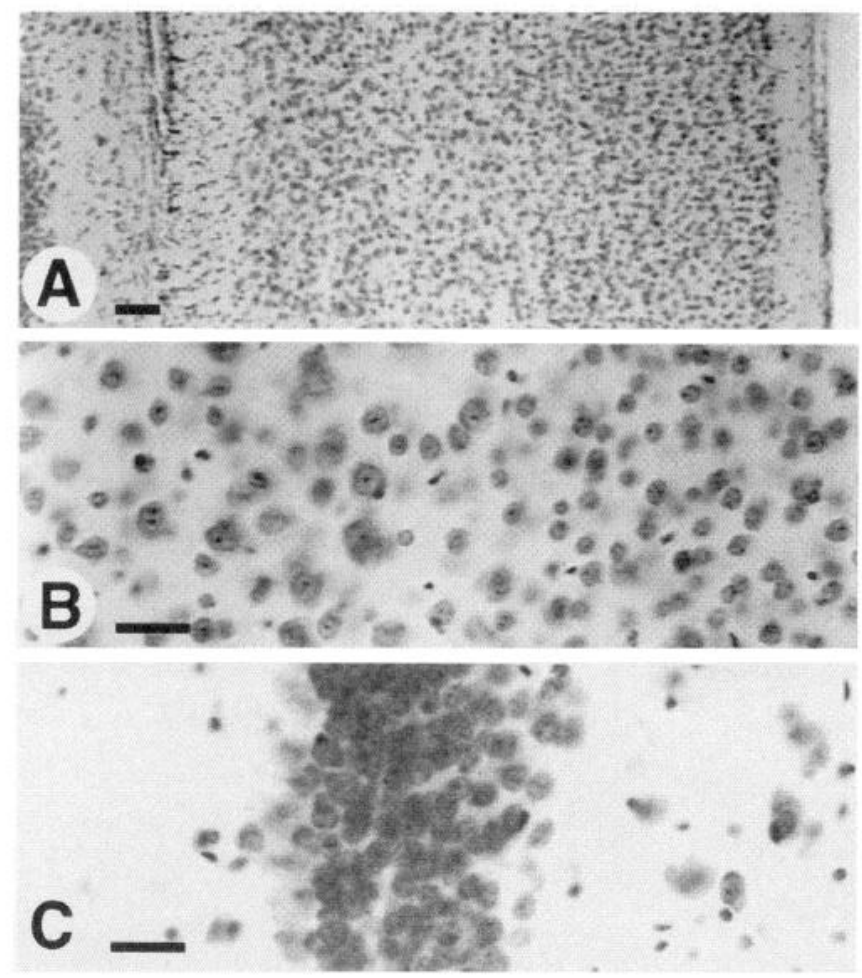

Figure 2. Cresyl violet-stained sections from the brain of a transgenic mouse expressing high levels of myc MAP2c. No abnormalities in either cell number or arrangement were detectable in either cerebral cortex $(A$, $B$ ) or hippocampus $(C)$. Positions are indicated for endogenous adult high $M_{\mathrm{r}}$ MAP2 (2b), embryonic MAP2 (2c), and tubulin $(T)$. Scale bars, $50 \mu \mathrm{m}$.

Immunohistochemical staining of brain sections from transgenic animals showed expression of myc-MAP2c in most brain regions, including the cerebral cortex, hippocampus, striatum, and cerebellum, but despite the high levels of expression there was no detectable disturbance of tissue structure or cell morphology. Cresyl violet-stained sections showed apparently normal arrangements of cell bodies in all brain areas (Fig. 2). Cell morphologies, as revealed by staining with various antibodies against cytoskeletal proteins (Fig. 3), were indistinguishable from those of nontransgenic control mice (data not shown). Despite the high level of expression, transgenic MAP2c was limited to cell bodies and dendrites within the cytoplasm of adult neurons (Fig. $3 A$ ). Its distribution was thus identical to that of adult high- $M_{\mathrm{r}}$ MAP2 (Fig. $3 B$ ) and readily distinguished from the axonal pattern of microtubule-associated protein tau (Fig. $3 C$ ). A comparable pattern of distribution was also evident in neuron-enriched cell cultures established from the hippocampi of transgenic animals that were stained simultaneously with antibodies against the myc epitope of transgenic MAP2c and with antibodies against tau (Fig. 4). The transgenic MAP2c was only present in cell bodies and dendrites (Fig. 4A), which were readily distinguishable from taulabeled axons (Fig. 4B). The presence of tau immunostaining along dendrites is caused by axons that run along the surface of dendritic processes in dispersed hippocampal neuron cultures (Goslin and Banker, 1991).

In a previous study, we observed that myc-MAP2c expressed in calcium phosphate-transfected primary hippocampal cultures entered all neuronal processes (Meichsner et al., 1993). This result obviously conflicts with the exclusively dendritic localization that we observed in both tissue sections and cultured neurons in the present study. To resolve this inconsistency, we repeated the transfection experiments with a new procedure that uses liposome-mediated transfection (Kaech et al., in press). Using this technique, we found that MAP2c was limited to the cell bodies and dendrites of transfected hippocampal neurons. This is shown by the identical immunohistochemical staining patterns for the myc epitope of transgenic MAP2c and endogenous adult MAP2 in Figure $5, A$ and $B$. The specificity of this distribution pattern was shown by expressing the similarly sized bacterial protein CAT from the same vector. In this case, the expressed protein appeared throughout the entire length of both dendrites and axons (Fig. $5 C$ ). These results indicate that there is no barrier to the entry of transgenically expressed foreign proteins into axons, and that the restriction of transgenic MAP2c to dendrites reflects the operation of a saturable endogenous sorting mechanism.

Currently known examples of cytoplasmic sorting of mRNAs depend on signals situated in their $3^{\prime}$-untranslated sequences (Kislauskis and Singer, 1992; Wilhelm and Vale, 1993). However, the myc-MAP2c construct used to produce our transgenic mice does not contain any untranslated sequence from the MAP2 mRNA, indicating that the mechanism responsible for its dendritic restriction depends on a signal situated within the coding sequence. This signal could reside in principle either in the protein sequence or in the nucleotide sequence of the mRNA. To distinguish between these alternatives, we determined the cellular location of endogenous adult MAP2 mRNA and the transgenic MAP2c mRNA in sections of mouse brain using specific oligonucleotide probes (Fig. 6). The transgenic MAP2c was located using a probe directed against the unique MAP2c sequence across the splice junction (Papandrikopoulou et al., 1989; Doll et al., 1990; Kindler et al., 1991). This probe gave clear labeling on sections of transgenic brain (Fig. 6A) and, as expected, there was no signal on brain sections from control nontransgenic animals (Fig. $6 B$ ). In both the CA region and dentate gyrus $(d g)$ region of the hippocampus, the MAP2c mRNA signal was restricted to the cell body layer (Fig. 6A). By contrast, a probe specific for endogenous adult high- $M_{\mathrm{r}}$ MAP2 mRNA confirmed its previously described dendritic location (Garner et al., 1988; Tucker et al., 1989) in both transgenic and control brain sections (Fig. 6C,D). For comparison, Figure $6, E$ and $F$, shows the contrasting cell body localization of tubulin mRNA.

\section{DISCUSSION}

By expressing embryonic MAP2c in the adult brain, this study provides new insights into the mechanisms that determine the targeting of structural proteins within the neuronal cytoplasm. Another objective of these experiments was to investigate the consequences of expressing embryonic MAP2c beyond the time when it normally disappears from the developing brain. Because at the end of the neonatal period MAP2c disappears from most brain regions and because inhibition of MAP2 expression during neuronal differentiation suppresses dendrite growth (Dinsmore and Solomon, 1991; Caceres et al., 1992; Sharma et al., 1994), it might have been expected that its prolonged expression would have a detectable and possibly informative effect on neuronal morphogenesis. However, even though one of our transgenic lines expressed MAP2c in the adult brain at levels exceeding those of endogenous high- $M_{\mathrm{r}} \mathrm{MAP} 2$, there was no detectable difference in neuronal morphology between these and control animals. In addition to the light microscopic and immunohistochemical data shown, we also analyzed tissue by Golgi staining and electron microscopy, neither of which revealed any detectable difference between MAP2c-transgenic and control animals. Although this 


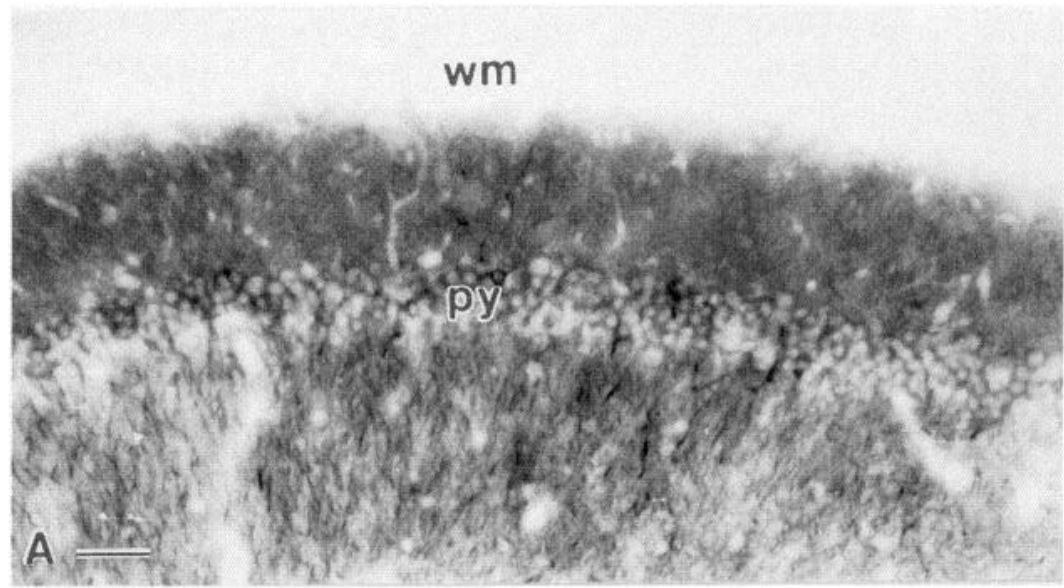

Figure 3. Immunohistochemical staining of sections from the CA1 region of the hippocampus from the brain of a transgenic mouse expressing high levels of MAP2c. A, Stained with monoclonal antibodies against the myc epitope to visualize transgenically expressed MAP2c. B, Neighboring section stained with monoclonal antibody AP14 that selectively labels the adult high $M_{\mathrm{r}}$ forms of MAP2. $C$, Neighboring section stained with rabbit polyclonal antiserum against microtubuleassociated protein tau (Goedert et al., 1989) that selectively labels tau in axons. The layer of pyramidal neuron cell bodies is labeled $p y$, and the overlying white matter axon tracts (alveus and corpus callosum) $\mathrm{wm}$. Scale bar, $100 \mu \mathrm{m}$.
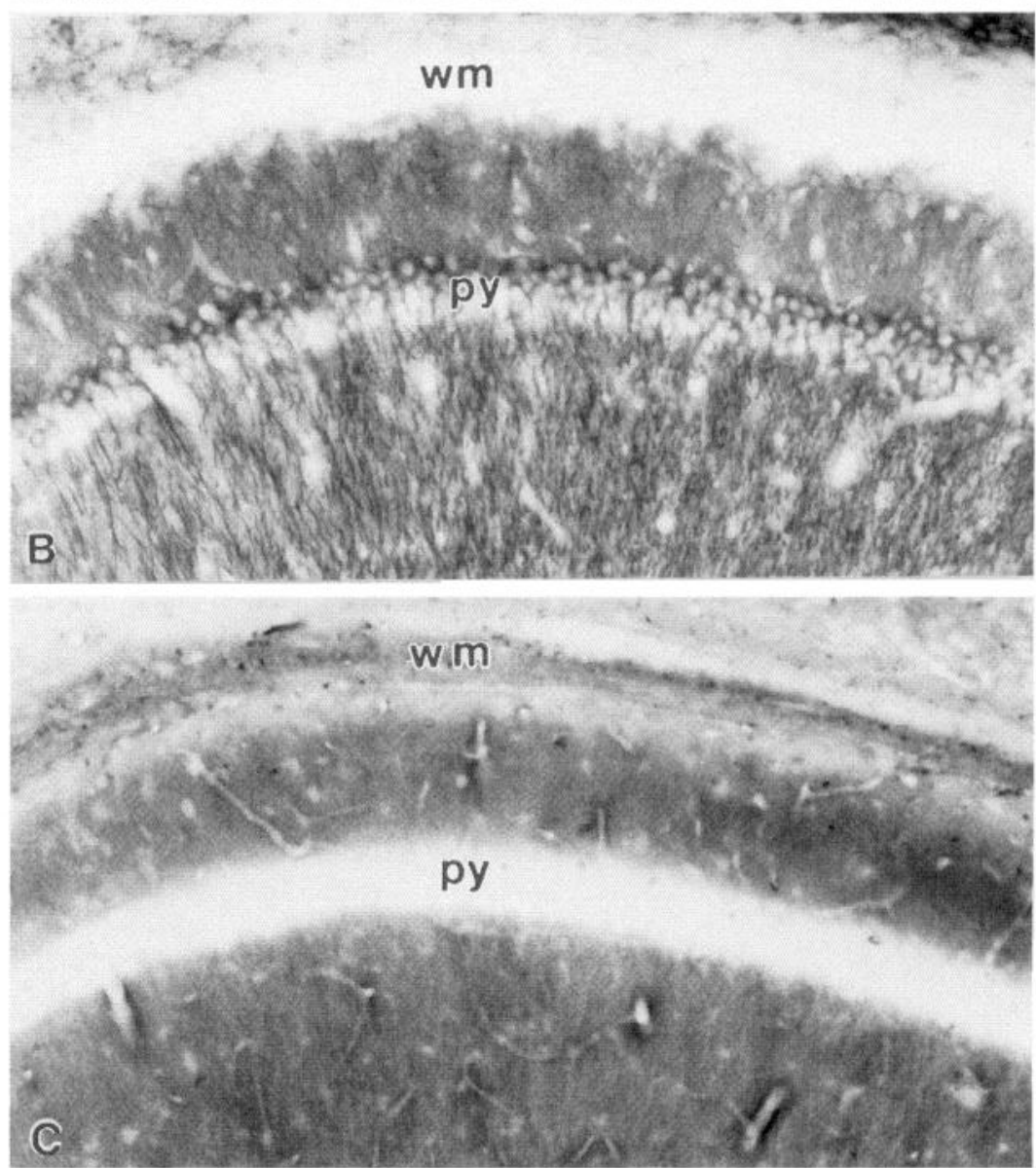

result at first seemed surprising, the situation may perhaps be compared to that of the olfactory system where, as an exception to the rest of the brain, neurons continue to express MAP2c during adulthood (Viereck et al., 1989; Viereck and Matus, 1990). Despite this, these cells are not morphologically "abnormal" compared to other neuronal types in the adult brain (Viereck et al., 1989; Viereck and Matus, 1990). MAP2c is also expressed in photosensitive cells of the adult retina (Tucker and Matus, 1988) that undergo a daily cycle of shedding and regenerating their outer segment disks, which are functionally equivalent to dendrites (Young, 1967). The distribution and intensity of anti-MAP2 staining in these photoreceptor cells does not vary during the light/dark cycle (Tucker and Matus, 1988), suggesting that MAP2c is not directly involved in regulating outer disk regeneration but that it is part of the machinery required for this to occur. Taken together with our present findings, these earlier results suggest that MAP2c provides a morphogenic potential that is only realized in tissues in which neuronal circuitry is being formed. Our transgenic mice may provide a model for evaluating the potential contribution of MAP2c to readjustments of circuitry after lesions to brain areas in which it is normally absent in the adult.

\section{Cytoplasmic distribution of transgenically expressed MAP2c}

Despite its high level of expression, transgenic MAP2c was restricted to dendrites in both tissue sections and cell cultures. This 


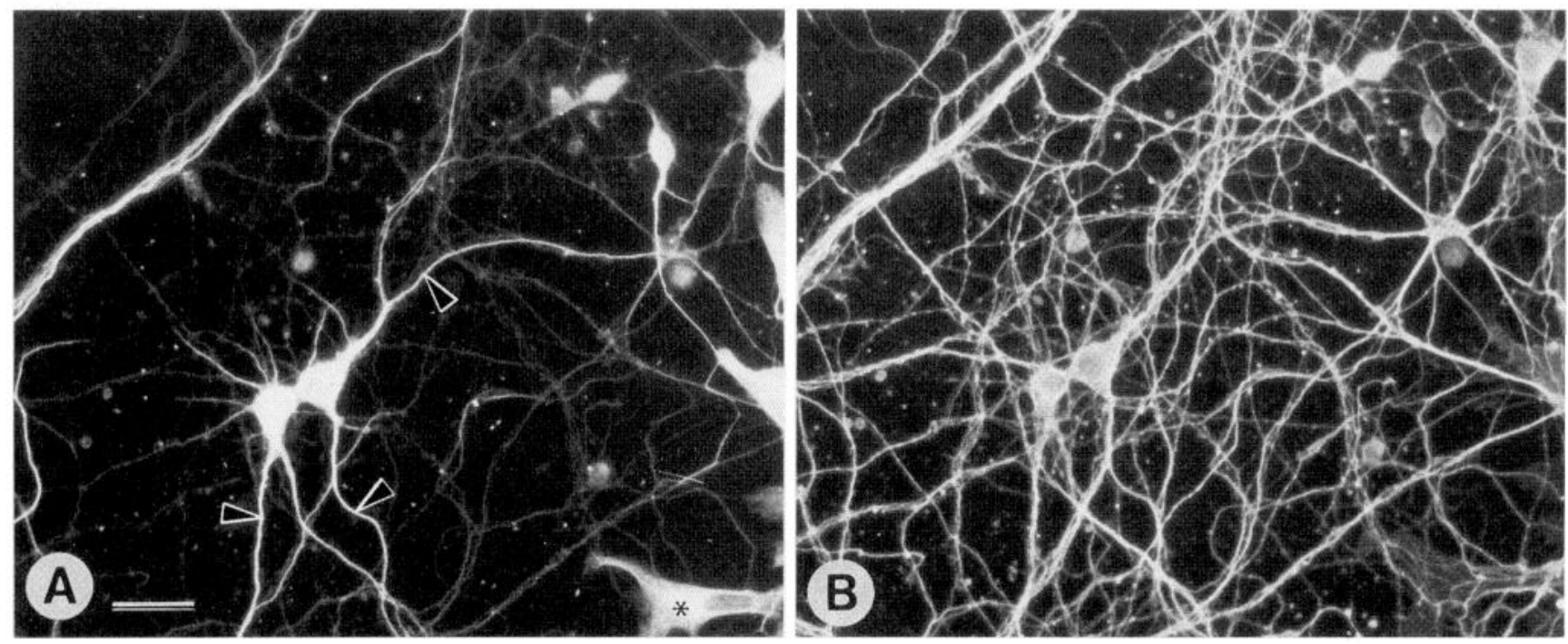

Figure 4. Dendritic localization of MAP2c in cultured hippocampal neurons from transgenic mice. Cultures established at embryonic day 16 and grown for $15 \mathrm{~d}$ were fixed and double-immunofluorescence-stained with anti-c-myc antibody for transgenic MAP2c (rhodamine; $A$ ) and rabbit antibody against tau (fluorescein; $B$ ). In $A$ some dendrites are identified by arrowheads. Preparations were also made using fluorescein to label anti-c-myc and rhodamine to label tau with identical results. Scale bar, $50 \mu \mathrm{m}$.

distribution mirrored that of endogenous adult MAP2 and contrasted strikingly with the axonal distribution of tau. It agrees with the dendritic localization of MAP2 found in most areas of both the adult and the developing nervous systems (Bernhardt and Matus, 1982; Bernhardt and Matus, 1984; Burgoyne and Cumming, 1984; De Camilli et al., 1984; Bernhardt et al., 1985). However, MAP2c-selective immunohistochemical staining is detectable in the axons of embryonic retinal ganglion cells (Tucker and Matus, 1988) and embryonic motor neurons (Tucker et al., 1988; Albala et al., 1995). It has also been reported that not only MAP2c but also high- $M_{\mathrm{r}}$ MAP2 is present in motor neuron axons (Papasozomenos et al., 1985). A possible reason for this is the exceptional length and diameter of the axons of these cell types, which may require MAP2 to lend additional stiffness to their microtubules (Matus, 1994). The exceptional nature of these cases is shown by the absence of MAP2c from axons of the rat olfactory tract, which contain high levels of another embryonic microtubule protein, MAP5 (MAP1B) (Viereck et al., 1989). Also in the olfactory bulb, where both MAP2c and high- $M_{\mathrm{r}}$ MAP2 are expressed, immunohistochemical staining patterns for the two forms are indistinguishable and limited to dendrites (Viereck et al., 1989). Although there are some exceptions, the available data suggest that in most neurons a mechanism exists, both during development and in adulthood, that sorts all forms of MAP2 to dendrites.

MAP2 sorting has also been investigated by transfecting primary neurons in cell culture. We initially reported that in rat hippocampal cells transfected in vitro epitope-labeled MAP2c entered both axons and dendrites (Meichsner et al., 1993). However, in the present study, despite high expression levels, MAP2c did not enter axons in cultured hippocampal neurons whether they were taken from transgenic animals or transfected in vitro using a liposome-mediated procedure (Kaech et al., in press). This suggests that the calcium phosphate transfection procedure used in our previous study may interfere with the normal sorting. Recently, it was reported that transfected MAP2c enters axons in cultured motor neurons (Kanai and Hirokawa, 1995). However, motor neurons belong to a relatively small group of neurons that contain immunoreactive MAP2 in their axons during normal development (Tucker et al., 1988; Albala et al., 1995). Furthermore Kanai and Hirokawa (1995) reported that MAP2c was not detectable in the axons of cultured embryonic motor neurons that had not been transfected, suggesting that in these cells, too, there is a preferential association of all MAP2 isoforms with the dendritic compartment under normal circumstances (Albala et al., 1995). On balance, the available data suggest that in most neurons both high- $M_{\mathrm{r}}$ MAP2 and MAP2c are sorted to dendrites.

In situ hybridization studies have shown that not only MAP2 protein but also its mRNA are present in neuronal dendrites (Bruckenstein et al., 1990; Kleiman et al., 1990). This raises the possibility that the dendritic localization of MAP2 might result from the previous sorting of the mRNA followed by local synthesis of the protein. However, in our transgenic mice, although MAP2c protein was localized in dendrites, its mRNA was present only in cell bodies. This indicates that the dendritic location of MAP2c protein depends on a signal situated on the protein itself. This signal must operate in such a way that for high- $M_{\mathrm{r}}$ MAP2 both the protein and mRNA are localized in the dendrite, whereas for MAP2c the protein enters the dendrite but the mRNA remains in the cell body. Figure 7 indicates a mechanism by which this could be achieved. In this scheme, a signal situated near the $\mathrm{N}$ terminus of the MAP2 protein, in a region common to both high- $M_{\mathrm{r}}$ MAP2 (MAP2b) and MAP2c, determines their transport into dendrites. For MAP2b this occurs during translation (Fig. 7, top), the period necessary for transport of the mRNA being provided by the length of time required to translate the $\sim 6$ $\mathrm{kb}$ of the MAP2b coding sequence, with the possible additional involvement of a pause signal within the nucleotide sequence (indicated as a loop in Fig. 7, top). For the much shorter coding sequence of MAP2c $(\sim 1.5 \mathrm{~kb})$, translation would be completed in the cell body, releasing the mRNA before transport of the protein into the dendrite (Fig. 7, bottom). In addition to the differential distribution of the two mRNAs, this mechanism can also account for the presence of ribosomes (Steward and Falk, 1991) and the active transport of ribosomal RNA into dendrites (Davis et al., 1987) as part of a MAP2 translation complex. 


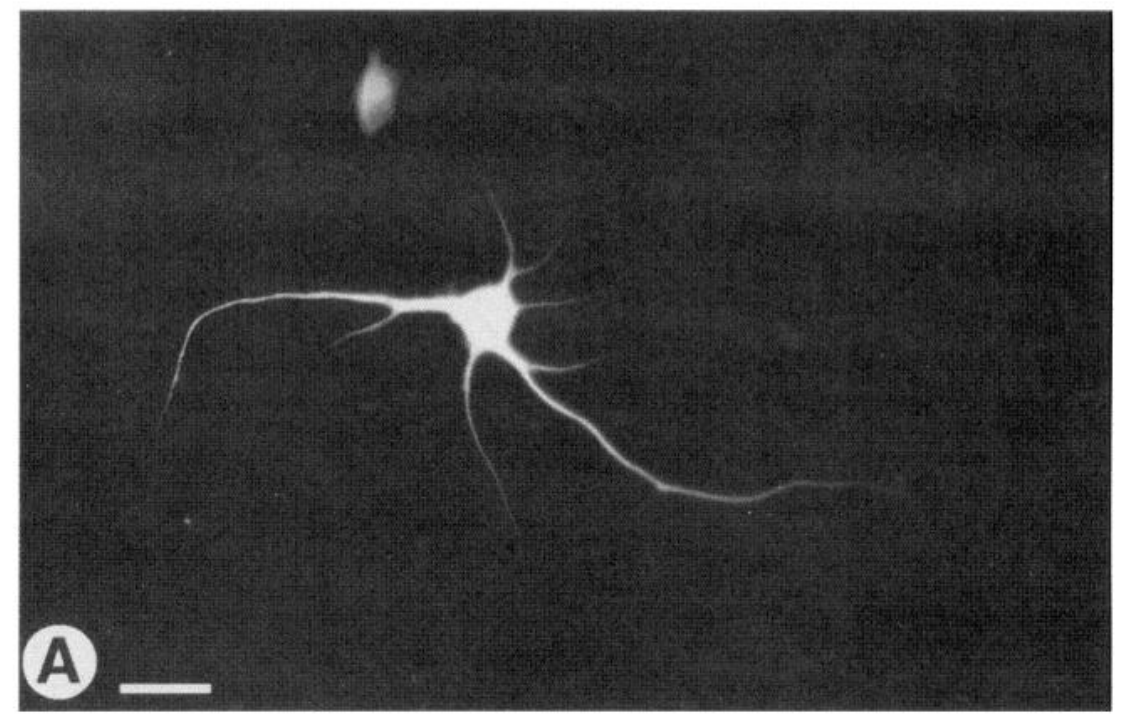

Figure 5. Location of myc-MAP2c in primary hippocampal neurons transfected in vitro. Cultures established at embryonic day 16 grown for $11 \mathrm{~d}$ were fixed and doubleimmunofluorescence-stained for the myc epitope of MAP2c (rhodamine; $A$ ) and for MAP2 (fluorescein; $B$ ). In the strongly expressing cell in $A$, transfected MAP2c shows the same dendritic localization as the endogenous adult MAP2 shown in $B$. A soluble test protein (CAT) expressed using the same promoter and transfection procedure is distributed throughout dendrites and axons $(C)$. Scale bar, $50 \mu \mathrm{m}$.
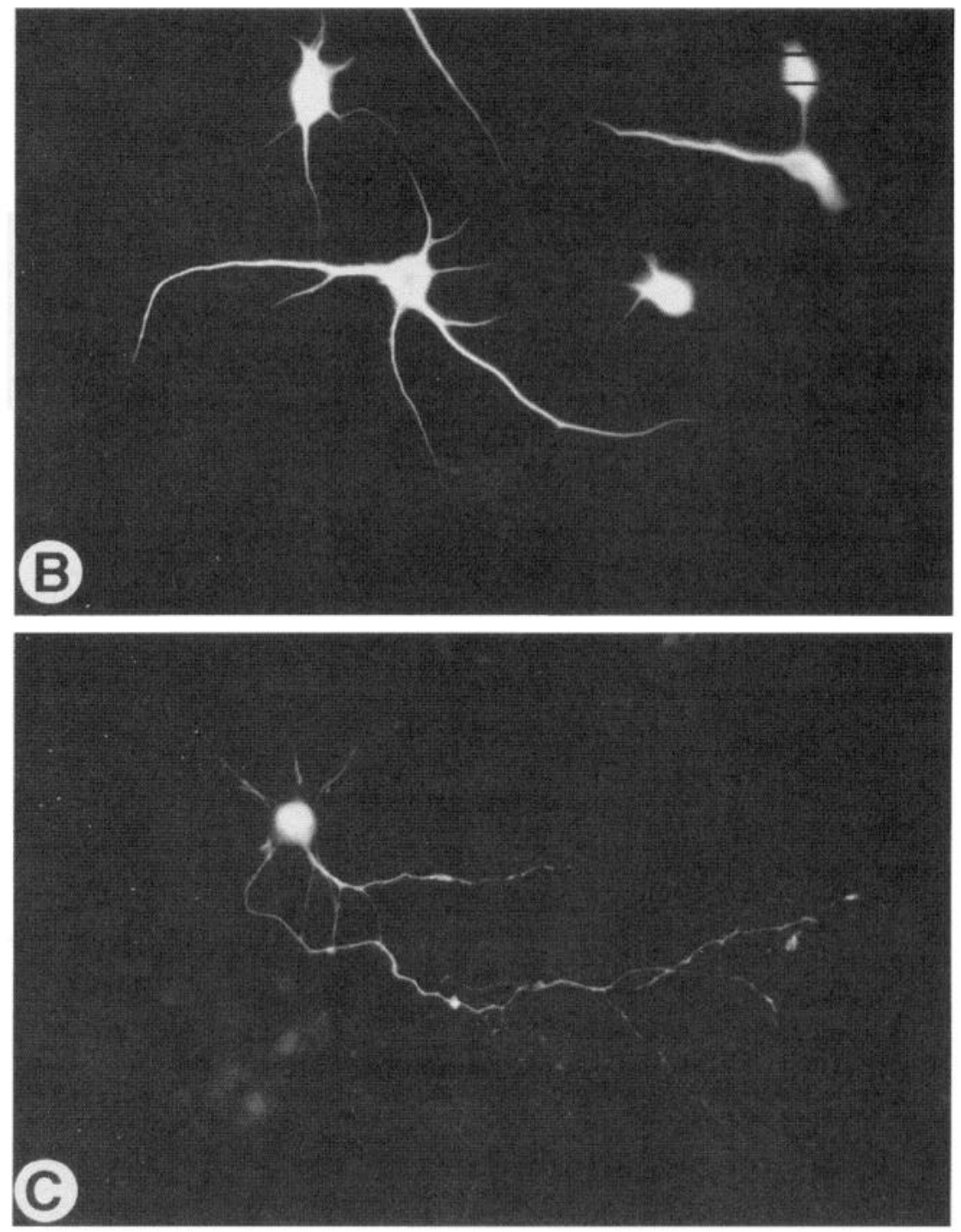

It is also possible that there are two independent mechanisms, one that sorts the MAP2 proteins to dendrites and another that operates selectively on the $9 \mathrm{~kb}$ mRNA of the high- $M_{\mathrm{r}}$ MAP2. It has been shown previously that inhibition of protein synthesis alters the distribution of mRNA in neurons so that mRNAs that are normally restricted to the cell body appear in the dendrites (Kleiman et al., 1993). One explanation for this finding is that mRNAs are retained in the cell body by a translation-dependent 

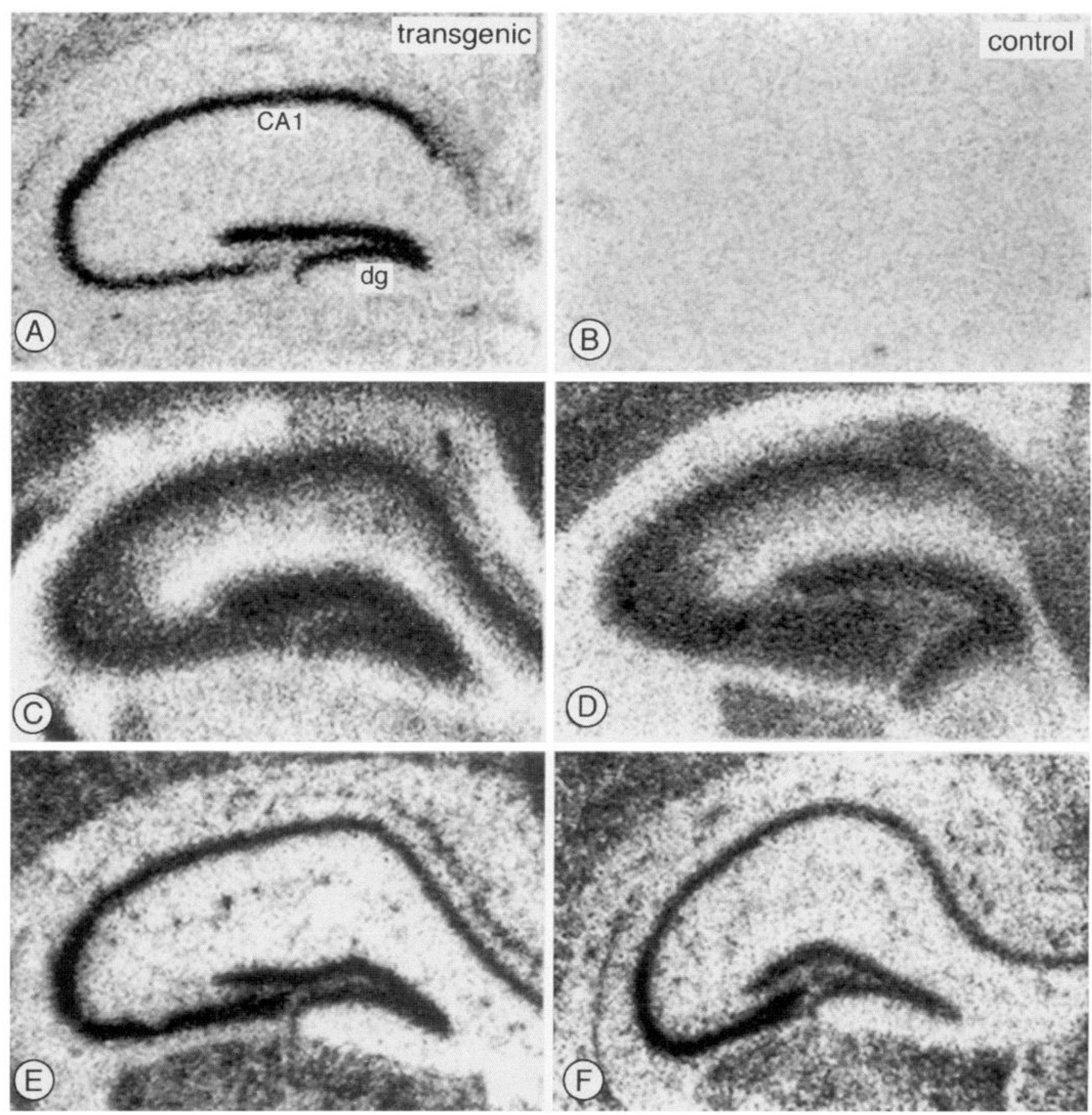

Figure 6. Localization of MAP2 and tubulin mRNAs in transgenic mouse hippocampus by in situ hybridization. Sections from brains of either transgenic (left) or control (right) mice were incubated with specific ${ }^{35} \mathrm{~S}$-labeled oligonucleotide probes, and the distribution of their target mRNAs was determined by autoradiography. Probes specific for the MAP2c-specific splice junction $(A, B)$ gave specific labeling only in transgenic brain sections, and this labeling was limited to cell body layer in both the CA region (labeled CA1) and dentate gyrus $(d g)$. By contrast, probes specific for endogenous high $M_{\mathrm{r}}$ MAP2 mRNA labeled both cell bodies and the adjacent dendrite-rich neuropil in both transgenic $(C)$ and control $(D)$ brains. A tubulin control probe labeled only cell body layers of CA1 and dentate gyrus neurons $(E, F)$. Scale bar, $0.5 \mathrm{~mm}$.

mechanism so that all mRNAs that are not translated are transported. Such a mechanism might operate selectively on high- $M_{\mathrm{r}}$ MAP2 under normal circumstances if its mRNA contained a conditional translation pause mechanism, such as that indicated in the hypothetical scheme of Figure 7. Such a mechanism would not operate on MAP2c, which lacks the central domain of MAP2 containing the putative pause signal (Papandrikopoulou et al.,
1989; Kindler et al., 1991). Its $6 \mathrm{~kb}$ mRNA consequently would remain in the cell body, where translation would occur followed by transport of the MAP2c protein into the dendrites.

Another factor relevant to the interpretation of our data is that approximately half the microtubules in dendrites have their "minus" ends oriented distally (Baas et al., 1988; Burton, 1988). Recent evidence indicates that this nonuniform polarity is estab- 
Figure 7. Diagrammatic representation of possible mechanisms for MAP2 transport signals. The large gray arrow represents the putative dendrite-directed transport mechanism. 1, A transport signal (green box) near the $\mathrm{N}$ terminus of the protein emerges during translation so that the translation complex, including the adult high- $M_{\mathrm{r}}$ protein $(2 b$ protein) and mRNA (Adult $m R N A)$ and ribosomes $(r b)$ are cotransported. A pause signal unique to the high- $M_{\mathrm{r}}$ mRNA (shown as a loop) may act as an additional feature mediating mRNA transport. 2, MAP2c mRNA (Embryonic $m R N A$ ), either because it is shorter or because it lacks a pause signal, completes its translation in the cell body so that only the protein is carried into the dendrite.

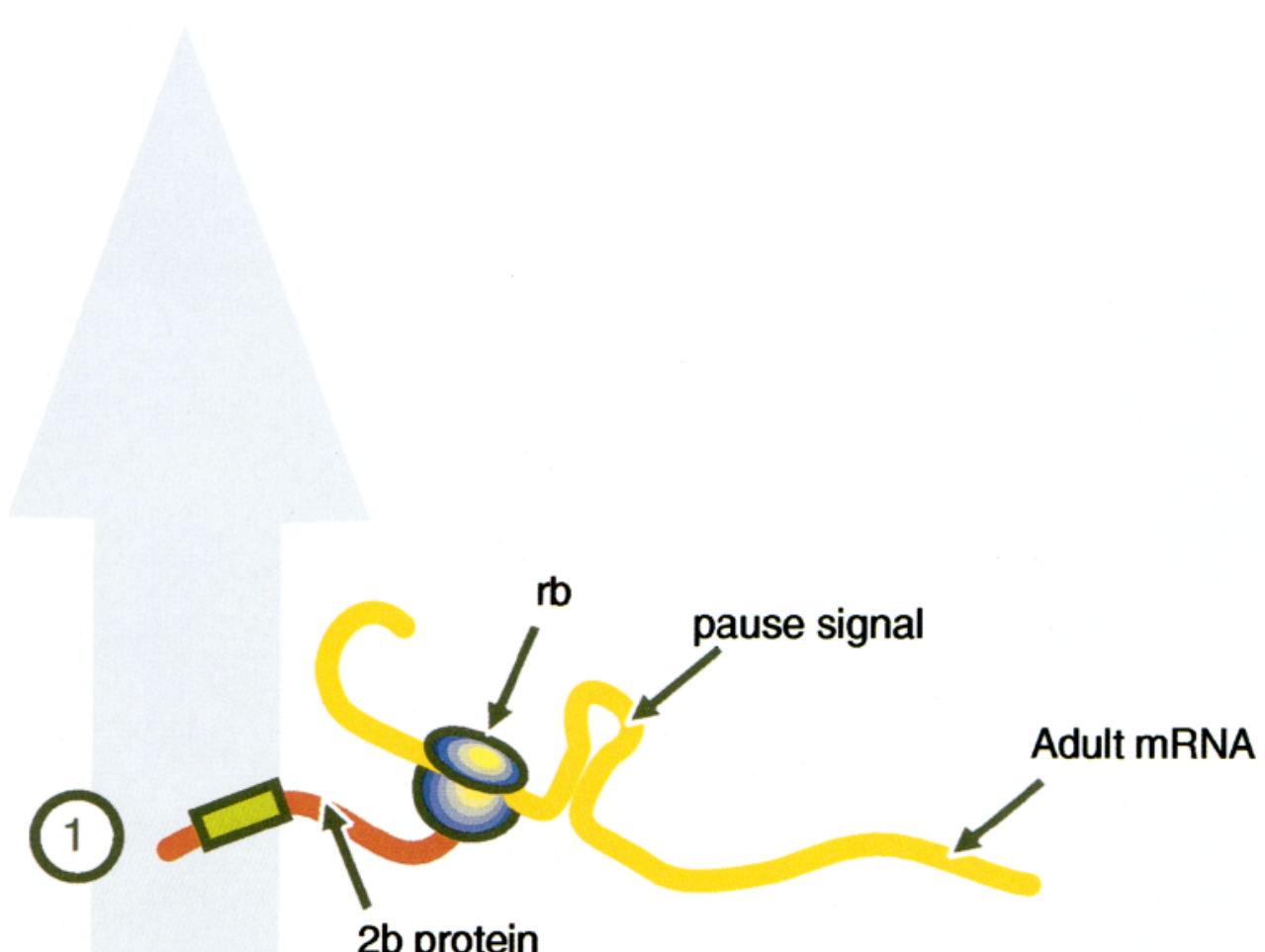

$2 \mathrm{~b}$ protein

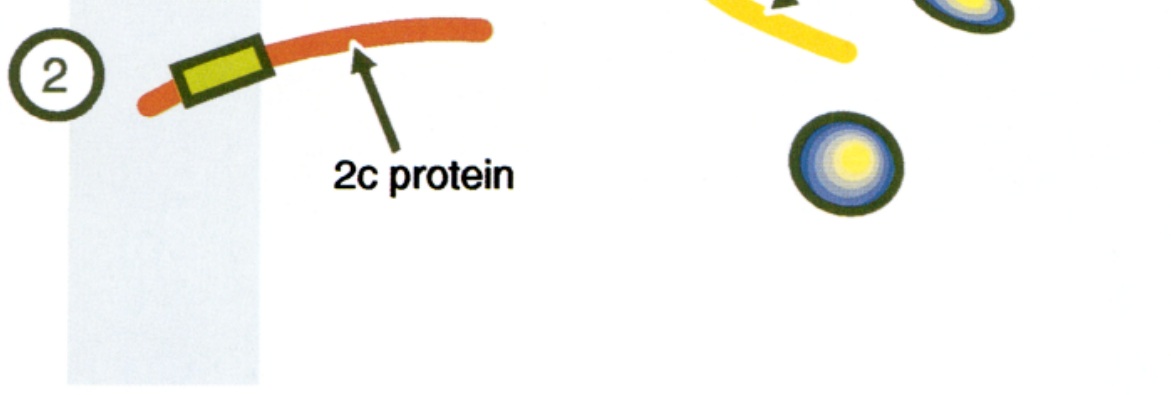

lished by the transport of assembled microtubules into dendrites with this orientation (Sharp et al., 1995). Because the appearance of "minus-end-out" microtubules is temporally correlated with the restriction of MAP2 to dendrites, it is possible that MAP2 might be transported into dendrites attached to this class of microtubules. Whatever the scheme involved, the dendritic localization of both high- and low- $M_{\mathrm{r}}$ MAP2 protein would require a signal common to the protein sequence of all forms. The fact that this signal involved is present in the 467 amino acids of MAP2c rather than the 1830 amino acids of the adult forms (Doll et al., 1990; Kindler et al., 1991) should greatly simplify the task of characterizing both the signal and the mechanism that operates on it.

\section{REFERENCES}

Albala JS, Kress Y, Liu W-K, Weidenheim K, Yen S-HC, Shafit Zagardo B (1995) Human microtubule-associated protein-2c localizes to dendrites and axons in fetal spinal motor neurons. J Neurochem 95:2480-2490.
Baas PW, Deitch JS, Black MM, Banker GA (1988) Polarity orientation of microtubules in hippocampal neurons: uniformity in the axon and nonuniformity in the dendrite. Proc Natl Acad Sci USA 85:8335-8339. Berleth T, Burri M, Thoma G, Bopp D, Richstein S, Frigerio G, Noll M, Nüsslein-Vollhard C (1988) The role and localization ofbicoid RNA in organizing the anterior pattern of the Drosophila embryo. EMBO J 7:1749-1756.

Bernhardt R, Matus A (1982) Initial phase of dendrite growth: evidence for the involvement of high molecular weight microtubule-associated proteins (HMWP) before the appearance of tubulin. J Cell Biol 92:589-593.

Bernhardt R, Matus A (1984) Light and electron microscopic studies of the distribution of microtubule-associated protein 2 in rat brain: a difference between dendritic and axonal cytoskeletons. J Comp Neurol 226:203-221.

Bernhardt R, Huber G, Matus A (1985) Differences in the developmental patterns of three microtubule-associated proteins in the rat cerebellum. J Neurosci 5:977-991.

Botteri FM, van der Putten H, Wong DF, Sauvage CA, Evans RM (1987) Mol Cell Biol 7:3178-3184. 
Bruckenstein DA, Lein PJ, Higgins D, Fremeau Jr R (1990) Distinct spatial localizations of mRNA in cultured sympathetic neurons. Neuron 5:809-819.

Burgin KE, Ludin B, Ferralli J, Matus A (1994) Bundling of microtubulcs in transfected cells docs not involvc an autonomous dimcrization site on the MAP2 molecule. Mol Biol Cell 5:511-517.

Burgoyne RD, Cumming R (1984) Ontogeny of microtubule-associated protein 2 in rat cerebellum: differential expression of the doublet polypeptides. Neuroscience 11:156-167.

Burton PR (1988) Dendrites of mitral cell neurons contain microtubules of opposite polarity. Brain Res 473:107-115.

Caceres A, Banker G, Steward O, Binder L, Payne M (1984) MAP2 is localized to the dendrites of hippocampal neurons which develop in culturc. Dev Brain Res 13:314-318.

Caceres A, Mautino J, Kosik KS (1992) Suppression of MAP2 in cultured cerebellar macroneurons inhibits minor neurite formation. Neuron 9:607-618.

Chen J, Kanai Y, Cowan NJ, Hirokawa N (1992) Projection domains of MAP2 and tau determine spacings of microtubules in dendrites and axons. Nature 360:674-677.

Craig AM, Banker G (1994) Neuronal polarity. Annu Rev Neurosci 17:267-310.

Davis L, Banker GA, Steward O (1987) Selective dendritic transport of RNA in hippocampal neurons in culture. Nature 330:477-479.

De Camilli P, Miller PE, Navone F, Theurkauf WE, Vallee RB (1984) Distribution of microtubule-associated protein 2 in the nervous system of the rat studied by immunofluorescence. Neuroscience 11:817-846.

Dinsmore JH, Solomon F (1991) Inhibition of MAP2 expression affects both morphological and cell division phenotypes of neuronal differentiation. Cell 64:817-826.

Doll T, Papandrikopoulou A, Matus A (1990) Nucleotide and amino acid sequences of embryonic rat MAP2c. Nucleic Acids Res 18:361.

Edson K, Weisshaar B, Matus A (1993) Actin depolymerisation induces process formation in MAP2-transfected non-neuronal cells. Development 117:689-700.

Fregien N, Davidson N (1986) Activating elements in the promoter region of the chicken beta-actin gene. Gene 48:1-11.

Garner CC. Matus A (1988) Different forms of microtubule-associated protein 2 are encoded by separate mRNA transcripts. J Cell Biol 106:779-783.

Garner CC, Tucker RP, Matus A (1988) Selective localization of messenger RNA for cytoskeletal protein MAP2 in dendrites. Nature 336:674-677.

Goedert M, Spillantini M G, Jakes R, Rutherford D, Crowther R A (1989) Multiple isoforms of human microtubule-associated protein tau: sequences and localization in neurofibrillary tangles of Alzheimer's disease. Neuron 3:519-526.

Goslin K, Banker G (1991) Rat hippocampal neurons in low-density culture. In: Culturing nerve cells (Goslin K, Banker G, eds), pp 252-282. Cambridge: MIT.

Greenough WT, West RW, DeVoogd TJ (1978) Subsynaptic plate perforations: changes with age and experience. Science 202:1096-1098.

Hill MA, Gunning P (1993) Beta and gamma actin mRNAs are differentially located within myoblasts. J Cell Biol 122:825-832.

Kaech S, Kim JB, Cariola M, Ralston E (1996) Improved lipid-mediated gene transfer into primary cultures of hippocampal neurons. Mol Brain Res, in press.

Kanai Y, Hirokawa N (1995) Sorting mechanisms of tau and MAP2 in neurons: suppressed axonal transport of MAP2 and locally regulated microtubule binding. Neuron 14:421-432.

Kindler S, Schulz B, Goedert M, Garner CC (1991) Molecular structure of microtubule-associated protein $2 \mathrm{~b}$ and $2 \mathrm{c}$ from rat brain. $\mathrm{J}$ Biol Chem 265:19679-19684.

Kislauskis EH, Singer RH (1992) Determinants of mRNA localization. Curr Opin Cell Biol 4:975-978.

Kleiman R, Banker G, Steward O (1990) Differential subcellular localization of particular mRNAs in hippocampal neurons in culture. Neuron 5:821-830.

Kleiman R, Banker G, Steward O (1993) Inhibition of protein synthesis alters the subcellular distribution of mRNA in neurons but docs not prevent dendritic transport of RNA. Proc Natl Acad Sci USA 90:11192-11196.
Lewis SA, Ivanov IE, Lee GH, Cowan NJ (1989) Organization of microtubules in dendrites and axons is determined by a short hydrophobic zipper in microtubule-associated and tau. Nature 342:498-505.

Matus A (1994) Stiff microtubules and neuronal morphology. Trends Neurosci 17:19-22.

Matus A, Bernhardt R, Hugh Jones T (1981) High molecular weight microtubule-associated proteins are preferentially associated with dendritic microtubules in brain. Proc Natl Acad Sci USA 78:3010-3014.

Matus A, Bernhardt R, Bodmer R, Alaimo D (1986) Microtubuleassociated protein 2 and tubulin are differently distributed in the dendrites of developing neurons. Neuroscience 17:371-389.

Meichsner M, Doll T, Reddy D, Weisshaar B, Matus A (1993) The low molecular weight form of microtubule-associated protein 2 is transported into both axons and dendrites. Neuroscience 54:873-880.

Melton DA (1987) Translocation of a localized maternal mRNA to the vegetal pole of Xenopus oocytes. Nature 328:80-82.

Munro S, Pelham HRB (1987) A C-terminal signal prevents secretion of luminal ER proteins. Cell 48:899-907.

Papandrikopoulou A, Doll T, Tucker RP, Garner CC, Matus A (1989) Embryonic MAP2 lacks the cross-linking sidearm sequences and dendritic targeting signal of adult MAP2. Nature 340:650-652.

Papasozomenos SC, Binder LI, Bender PK, Payne MR (1985) Microtubule-associated protein 2 within axons of spinal motor neurons: associations with microtubules and neurofilaments in normal and beta, beta'-iminodipropionitrile-treated axons. J Cell Biol 100:74-85.

Riederer B, Matus A (1985) Differential expression of distinct microtubule-associated proteins during brain development. Proc Natl Acad Sci USA 82:6006-6009.

Sharma N, Kress Y, Shafit Zagardo B (1994) Antisense MAP-2 oligonucleotides induce changes in microtubule assembly and neuritic elongation in pre-existing neurites of rat cortical neurons. Cell Motil Cytoskeleton 27:234-247.

Sharp DJ, Yu W, Baas PW (1995) Transport of dendritic microtubules establishes their nonuniform polarity orientation. J Cell Biol 130:93-104.

Steward O, Falk PM (1991) Selective localization of polyribosomes beneath developing synapses: a quantitative analysis of the relationships between polyribosomes and developing synapses in the hippocampus and dentate gyrus. J Comp Neurol 314:545-557.

Sundell CL, Singer RH (1990) Actin mRNA localizes in the absence of protein synthesis. J Cell Biol 111:2397-2403.

Towbin H, Staehelin T, Gordon J (1979) Electrophoretic transfer of protein from polyacrylamide gels to nitrocellulose sheets: procedure and some applications. Proc Natl Acad Sci USA 76:4350-4354.

Tucker RP, Matus AI (1988) Microtubule-associated proteins characteristic of embryonic brain are found in the adult mammalian retina. Dev Biol 130:423-434.

Tucker RP, Binder LI, Matus AI (1988) Neuronal microtubuleassociated proteins in the embryonic avian spinal cord. J Comp Neurol 271:44-55.

Tucker RP, Garner CC, Matus A (1989) In situ localization of microtubule-associated protein mRNA in the developing and adult rat brain. Neuron 2:1245-1256.

Vallee RB (1982) A taxol dependent procedure for the isolation of microtubules and microtubule-associated proteins. J Cell Biol 92:435-442.

Viereck C, Matus A (1990) The cxpression of phosphorylated and nonphosphorylated forms of MAP5 in the amphibian CNS. Brain Res 508:257-264.

Viereck C, Tucker RP, Matus A (1989) The adult rat olfactory system expresses microtubule-associated proteins found in the developing brain. J Neurosci 9:3547-3557.

Weisshaar B, Doll T, Matus A (1992) Reorganisation of the microtubular cytoskeleton by embryonic microtubule-associated protein 2 (MAP2c). Development 116:1151-1161.

Wilhelm JE, Vale RD (1993) RNA on the move: the mRNA localization pathway. J Cell Biol 123:269-274.

Yisraeli JK, Melton DA (1988) The maternal mRNA Vgl is correctly localized following injection into Xenopus oocytes. Nature 336:592-595.

Young RW (1967) The renewal of photoreceptor outer segments. J Cell Biol 33:61-72. 